\title{
Predation on gastropods by shell-breaking crabs: effects on shell availability to hermit crabs
}

\author{
Alexander Turra ${ }^{1,2, *}$, Márcia R. Denadai ${ }^{1}$, Fosca P. P. Leite ${ }^{1}$ \\ ${ }^{1}$ Departamento de Zoologia, PG-Ecologia, Instituto de Biologia, Unicamp, Campinas, 13083-970, São Paulo, Brazil \\ ${ }^{2}$ Present address: Laboratório de Biologia Aquática, Curso de Ciências Biológicas, Campus II, UNIFEOB, \\ São João da Boa Vista, 13870-159, São Paulo, Brazil
}

\begin{abstract}
This study addressed the effect predation on gastropods by shell-breaking crabs has on shell availability to hermit crabs. (1) Variable rates of predation on the gastropod Cerithium atratum were recorded within and among the crab species Menippe nodifrons, Panopeus occidentalis, Eriphia gonagra, and Callinectes danae. Predation rate was more dependent on crab size than on crab species, and all predators consumed the largest individuals of C. atratum available. Comparison of $M$. nodifrons and $C$. danae predation of the rocky shore gastropods Stramonita haemastoma, Morula nodulosa, and Tegula viridula revealed that only $M$. nodifrons consumed M. nodulosa, while both crabs preyed more heavily upon $S$. haemastoma than on $T$. viridula. $M$. nodifrons crushed larger individuals of Stramonita. (2) Prey subjected to M. nodifrons and C. danae presented different critical sizes $(S$. haemastoma $>T$. viridula $=M$. nodulosa. (3) The investment in shell material varied among gastropod species ( $M$. nodulosa $>T$. viridula $>S$. haemastoma) and was inversely related to their consumption rate by $M$. nodifrons. (4) M. nodifrons generally crushed its prey, C. danae and E. gonagra used both peeling and crushing, and P. occidentalis generally peeled. Crushing was usually lethal, while peeling attempts resulted in higher prey survival. Predatory strategy was dependent on relative prey size: small shells were crushed, medium-sized were peeled, and large ones were nondestructively preyed upon through the aperture. (5) Most shells used by the hermit crab Pagurus criniticornis $(68 \%)$ in nature presented damage very similar to that recorded for gastropods preyed upon experimentally, indicating that this kind of predation makes new shells available to hermit crabs. (6) M. nodifrons showed a clear preference for the gastropod C. atratum over the hermit crab $P$. criniticornis, suggesting differential predation pressures in nature. In conclusion, shell availability to hermit crabs was demonstrated to be dependent on predator species and size, gastropod architectural defenses, and on the relative predator-prey size, which determined the predatory strategy and the damage inflicted on the shells.
\end{abstract}

KEY WORDS: Predation · Gastropods $\cdot$ Hermit crabs $\cdot$ Shell availability $\cdot$ Shell utilization $\cdot$ Intertidal · Shell-breaking crabs

Resale or republication not permitted without written consent of the publisher

\section{INTRODUCTION}

Gastropods and hermit crabs are important components of intertidal and shallow subtidal communities (Leite et al. 1998) and may have an important role in community organization. Hermit crabs generally shelter their soft abdomens in gastropod shells, which may directly influence their biology. Empty shells are generally in short supply in nature (Chil- dress 1972, Vance 1972a, Kellogg 1976, Bertness 1980, but see Turra \& Leite 2001) and, although hermit crabs have adaptations for finding shells prior to their removal from a given area (Rittschof 1980, Mesce 1982), shells are thought to be a limiting resource. In fact, there is strong evidence supporting the positive effect of shell availability on hermit crab populations (Vance 1972a, Spight 1977, Wilber \& Herrnkind 1984). 
Bertness (1980) pointed out that effective shell availability to hermit crabs depends on the cause of gastropod deaths. Desiccation and other non-destructive causes (e.g. parasitism) may leave intact shells, while predation may completely destroy them. In fact, gastropods and hermit crabs are subjected to many predatory species, such as gastropods, fishes, octopuses, lobsters, and brachyuran crabs, and predation on hermit crabs has been demonstrated to be very important in reducing crab abundance in nature (Bertness \& Cunningham 1981, Borjesson \& Szelistowski 1989, Kuhlmann 1992). Batfish may entirely swallow smallsized shells, thus making intact shells available (Gibran \& Castro 1999), while spiny puffer fish completely crush their prey (Bertness et al. 1981). Drilling gastropods (Wilber \& Herrnkind 1984) and octopuses (McLean 1983, Cortez et al. 1998) make holes in the shells of their prey, which are then avoided by intertidal hermit crabs in shell-selection experiments (Pechenik \& Lewis 2000). Predation by crabs or lobsters on both gastropods and hermit crabs may also cause complete or partial destruction of shells (Shoup 1968, Rossi \& Parisi 1973, Vermeij 1978, Zisper \& Vermeij 1978, Bertness \& Cunningham 1981, McLean 1983, Lau 1987, Angel 2000). Such predation may have a negative effect on hermit crab populations through reduction of shell availability, as damaged shells are strongly avoided by hermit crabs (Vance 1972a, Pechenik \& Lewis 2000). Bertness \& Cunningham (1981) have estimated the number of damaged shells originating from shell-breaking predation that are used by hermit crabs. Nevertheless, there are no data addressing the effect these predators have on shell availability to hermit crabs by comparing the types of damage produced by shell-breaking crabs with the physical condition of shells used by hermit crabs in nature. A series of experiments were, therefore, carried out to evaluate the predatory tactics and types of damage caused by 4 common intertidal and shallow subtidal predators (Menippe nodifrons, Panopeus occidentalis, Eriphia gonagra, and Callinectes danae) to the shells of the sympatric gastropod Cerithium atratum. Shells of this species are the main resource used by the coexisting hermit crab Pagurus criniticornis in the Araçá region, a tidal flat in SE Brazil (Leite et al. 1998, Turra \& Leite 2002). The types of damage recorded in the laboratory were compared to those recorded from the shells used by this hermit crab species in nature, to evaluate to what extent shell availability to hermit crabs is dependent on gastropod predation by shell-breaking crabs.

Prey preferences of shell-breaking crabs have been demonstrated to vary between gastropods and hermit crabs, depending on the gastropod shell used (Rossi \& Parisi 1973). It is important, therefore, to determine if predators prefer the gastropod Cerithium atratum or the hermit crab Pagurus criniticornis using such shells, so as to understand which organisms are subjected to higher predation pressure in nature.

Inadequate shells may restrict hermit crab growth (Markham 1968, Fotheringham 1976a, Bertness 1981a, Angel 2000), fecundity (Childress 1972, Fotheringham 1976b), and survivorship (Reese 1969, Taylor 1981, Angel 2000). Gastropod shells also provide protection against desiccation (see Turra \& Denadai 2001) and predation (Bertness \& Cunningham 1981), although protective capabilities of shells have been demonstrated to vary among gastropod species (Vermeij 1978, Bertness 1981b, Bertness \& Cunningham 1981, Lively 1988). As predation on shells is thought to be more dependent on mechanical limitations, i.e. the relative strengths and sizes of crabs and shells (Zisper \& Vermeij 1978, Juanes 1992, Yamada \& Boulding 1998), hermit crabs may encounter refuge from predation when using shells larger than the critical size (sensu Vermeij 1978) attained by each gastropod species. In a broader sense, evaluating the effects of predators on their gastropod prey is especially important given the top-down control predators may have in coastal intertidal communities and upon ecosystem primary production (Silliman \& Bertness 2002).

In this context, some questions were addressed in a tidal flat in SE Brazil: (1) Does the predation rate and critical prey size depend on predator species? This question was tested by comparing the predation rate and critical size (largest prey consumed) of Cerithium atratum, a common intertidal soft-bottom gastropod, among 4 coexisting shell-breaking crabs (Menippe nodifrons, Panopeus occidentalis, Eriphia gonagra, and Callinectes danae) and by comparing the predation rate and critical sizes of Stramonita haemastoma, Tegula viridula, and Morula nodulosa, common intertidal hard-bottom gastropods, between $M$. nodifrons and C. danae. (2) Does critical prey size vary among different gastropod species subjected to the same predator? This question was addressed by comparing the critical size of the preyed- upon individuals of $S$. haemastoma, T. viridula, and $M$. nodulosa for each predator species, $M$. nodifrons and $C$. danae, independently. (3) Does the predation rate reflect prey investment in shell architectural defenses? This was evaluated by relating the predation rate of $M$. nodifrons and $C$. danae on the 3 rocky shore gastropods $S$. haemastoma, $T$. viridula, and $M$. nodulosa to their investment in shell material. (4) Does the predatory strategy depend on predator species or prey size? This was evaluated by contrasting the shell-breaking strategies of different predator species on prey of different sizes. (5) Does the type of damage recorded in shells used by hermit crabs in nature reflect previous predation 
events by shell-breaking crabs? This question was answered by contrasting the damage types inflicted on the $C$. atratum shells in the predation experiments with those recorded in shells of this species used by the sympatric hermit crab Pagurus criniticornis. (6) Does the predation pressure differ between gastropods and hermit crabs? This was tested by comparing the preference of $M$. nodifrons for $C$. atratum or the hermit crab P. criniticornis.

\section{MATERIALS AND METHODS}

Consumption rate and critical size (Questions 1 and 2). This experiment was designed to test the consumption rate of the gastropod Cerithium atratum (see Fig. 4) by the crabs Menippe nodifrons, Panopeus occidentalis, and Eriphia gonagra, and by the blue crab Callinectes danae. These are very common intertidal and shallow subtidal species along the Brazilian coast, and are especially abundant in the Araçá region $\left(23^{\circ} 49^{\prime} \mathrm{S}, 45^{\circ} 24^{\prime} \mathrm{W}\right)$, São Sebastião Channel, SE Brazil. In this area they coexist with a hermit crab ensemble (Turra et al. 2000) and with the gastropod C. atratum (Leite et al. 1998, Turra \& Leite 2002), whose shells are the main resource used by the small-sized hermit crabs Clibanarius antillensis and Pagurus criniticornis (Leite et al. 1998).

The consumption rate was defined as the mean number of prey consumed by each predator species per day. The predators (20 individuals of each species: Menippe

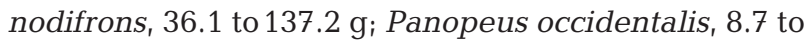
$29.5 \mathrm{~g}$; Eriphia gonagra, 9.8 to $51.1 \mathrm{~g}$; Callinectes danae, 34.1 to $89.0 \mathrm{~g}$ ) were starved for $72 \mathrm{~h}$ before trials and then put in individual experimental tanks $(40 \times 70 \times$ $40 \mathrm{~cm}$ ) with running seawater. Sex and sexual maturity of crabs were not controlled and the experiment was conducted in a $12 \mathrm{~h}$ light:12 h dark photoperiod with water temperature varying between 22 and $24^{\circ} \mathrm{C}$. The bottoms of the tanks were not filled with sand to avoid confounding effects due to gastropods burrowing (A. Turra pers. obs.). The water level was maintained at $5 \mathrm{~cm}$ to prevent climbing and, consequently, predation avoidance by the gastropods. C. atratum individuals, comprising the entire size range (15.50 to $34.10 \mathrm{~mm}$ ) of the species in the field, were collected, measured (shell length, mm), and individually marked. Twenty $1 \mathrm{~mm}$ size classes were identified and 1 individual of each size class was offered to each predator (20 individuals in total). Observations were made daily during 3 subsequent days. During each observation, the consumed C. atratum individuals were recorded and replaced in the tanks by other individuals of the same size class. The damage caused to the prey was also noted. The critical size was the size of the largest prey consumed by a predator of a given species and size. The mean consumption rate (prey $\mathrm{d}^{-1}$ ) was compared among predator species using a 1-way ANOVA (followed by a multiple comparison Tukey's HSD test, Zar 1999) to test the null hypothesis that the consumption rate was similar among predator species. Analysis of covariance (ANCOVA) was also employed using predator weight as the covariate, to estimate the effect of predator size on the consumption rate. The 1-way ANOVA and the ANCOVA (predator weight as covariate) were also employed to test the null hypothesis of equality in the mean number of unsuccessful attempts (living gastropods with damaged shells) and in the mean rate of successful predation (successful attempts/successful + unsuccessful attempts) among predator species. The null hypothesis that the critical size of $C$. atratum was the same for all predator species was tested by ANCOVA, using predator size as covariate.

The predation rate and critical size of the other gastropod species Stramonita haemastoma, Morula nodulosa, and Tegula viridula (Fig. 1) were tested in another series of experiments using Menippe nodifrons and Callinectes danae as shell-breaking crabs. These gastropod species are very abundant in the intertidal and shallow subtidal rocky shores of the SE Brazilian coast

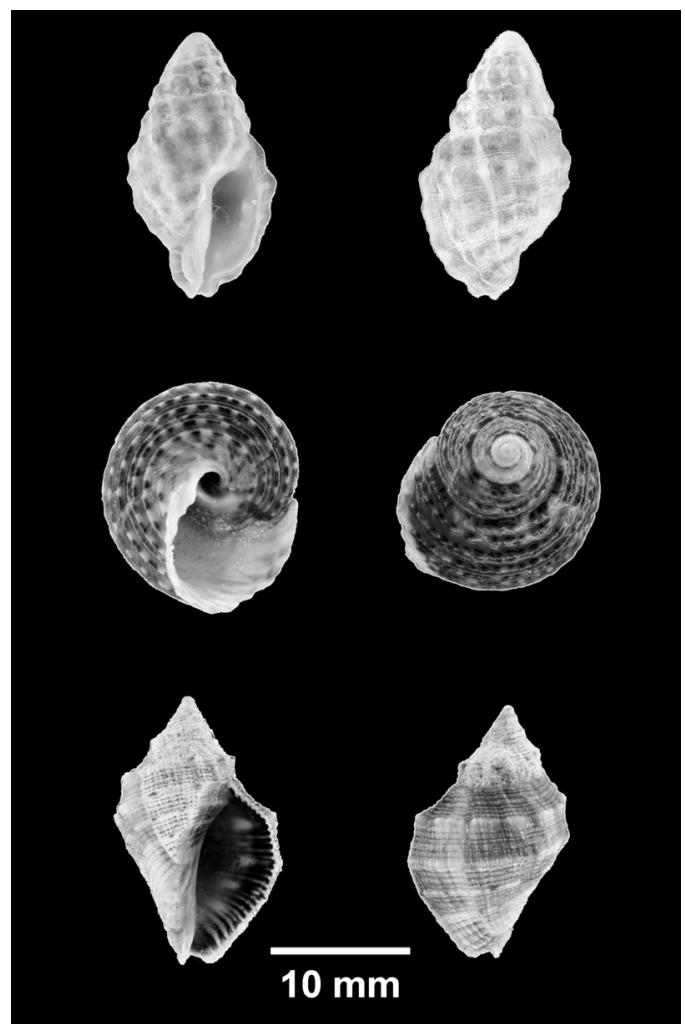

Fig. 1. Morula nodulosa, Tegula viridula, and Stramonita haemastoma shells (from top to bottom) used in predation experiments 
(Magalhães 2000), and their shells are also frequently used by coexisting hermit crabs (Leite et al. 1998). The laboratory protocol used was the same as in previous procedures. Nine crabs (replicates) of each predator species were used (M. nodifrons, 17.2 to $295.1 \mathrm{~g} ; C$. danae, 37.4 to $101.4 \mathrm{~g}$ ). Eight prey representing the entire size range sampled in the field were offered to each crab (shell length: $S$. haemastoma, 11.45 to $55.25 \mathrm{~mm} ; \mathrm{M}$. nodulosa, 11.15 to $21.35 \mathrm{~mm}$; T. viridula, 3.20 to $17.55 \mathrm{~mm}$ ). All gastropods were measured (shell length, $\mathrm{mm}$ ) and individually marked prior to experiments. Daily observations were made over $7 \mathrm{~d}$ and the number of prey consumed, their sizes and the types of damage inflicted were recorded. During each observation, if none of the shells had been preyed on, smaller shells were added; if the largest one had been preyed on, larger shells were added. This procedure was based on Bertness \& Cunningham (1981). The number and size of all predated gastropods were recorded, and the consumption rate and the critical sizes of the 3 gastropod species were compared between the 2 predator species with the Student's $t$ test (Zar 1999). The consumption rate of the 2 predators and the critical sizes of individuals preyed upon were also compared among gastropod species with the paired Student's $t$-test (Zar 1999; Bonferroni probability correction for 2 comparisons: $p=0.025$ ). The predatory strategy (crushing) was controlled in the analysis of critical sizes to make comparisons more reliable; this was done only for $M$. nodifrons because $C$. danae did not prey upon $M$. nodulosa and there were no sufficient data to compare critical sizes between $S$. haemastoma and $T$. viridula controlling predatory strategy.

Gastropod investment in architectural defense (Question 3). A sample of individuals from all size classes of each gastropod species (Cerithium atratum, Stramonita haemastoma, Morula nodulosa, and Tegula viridula) was used to relate shell weight (dependent variable) to the dry weight of animal soft parts. Data on Cerithium was the same as that in used previous analyses. A linear model $(y=a+b x)$ was used to describe the relationship between these 2 variables. Covariance analysis (ANCOVA) was employed to address the null hypothesis that investment in shell material (shell weight) in relation to dry weight of soft parts did not differ among gastropod species. The slopes (b) of the fitted models were compared through a Tukey-type multiple comparison test (Zar 1999).

Predatory strategy (Question 4). The types of shell damage caused by predators were recorded in the experiments cited above. According to Vermeij (1978), crabs may prey on gastropod shells through peeling, breaking the shell through the aperture and body whorl, and crushing, causing more severe damage to the shells. Other predatory strategies have also been reported. The predatory strategies were then compared among the 4 shell-breaking crabs that preyed upon Cerithium atratum (Menippe nodifrons, Eriphia gonagra, Panopeus occidentalis, and Callinectes danae). The sizes of crushed and peeled shells were compared for each species with the Student's $t$-test.

Similar comparisons were made for the shells of Stramonita haemastoma, Tegula viridula, and Morula nodulosa preyed on by Menippe nodifrons and Callinectes danae. The weight of individuals of both predators was also correlated (Pearson correlation, Zar 1999) with the largest consumed (all strategies pooled), largest peeled, largest crushed, and largest, intact, preyed-upon $S$. haemastoma individual, to evaluate if critical size of this gastropod species was correlated to crab size.

Damage to Cerithium atratum shells: experiments versus those used by Pagurus criniticornis in the field (Question 5). The types of damage to C. atratum shells caused by the 4 predator species in the laboratory experiments were compared to the damage observed in shells of this species used by $P$. criniticornis in the field. The hermit crab population was sampled by dredging (1 $\mathrm{mm}$ mesh size) the study area during high tides. The sediment was washed with seawater in $1 \mathrm{~mm}$ sieves and the shell species and the types of damage (based on laboratory observations) were recorded for all individuals.

Predation by Menippe nodifrons: Pagurus criniticornis versus Cerithium atratum (Question 6). The preference of the shell-breaking crab $M$. nodifrons for the gastropod C. atratum or the hermit crab P. criniticornis (in C. atratum shells) was evaluated. One individual of each prey species with similar shell size (shell length) was offered to each predator in small, circular, plastic trays $(0.25 \mathrm{~m}$ in diameter) with running seawater. A total of 24 pairs were used in this experiment. Twenty-four hours prior to experimentation, a large number of empty gastropod shells were offered to the hermit crabs to assure that they were in their ideal/optimal shells. This procedure was undertaken to minimize the higher susceptibility to predation by crabs when in sub-optimal shells (Angel 2000). The first species consumed by each crab was considered to be the preferred prey. The number of prey of each species preferred by $M$. nodifrons was compared through a log-likelihood G-test (Zar 1999) to test the null hypothesis that this shell-breaking crab species does not show prey-species preferences.

The preference of the predator for a given prey may be a consequence of differences in biomass; therefore, the null hypothesis that the weight of the soft parts (independent variable) of both gastropod and hermit crab are equally related to shell weight (dependent variable) was tested. Thus, a field sample of gastropods was employed to evaluate their shell weight and dry 
weight of soft parts. A shell-size selection experiment was carried out, offering 20 Cerithium atratum shells of variable sizes to Pagurus criniticornis individuals of a wide size range. After $24 \mathrm{~h}$, the crabs were removed from the selected shells, and the dry weight of shells and crabs were recorded. Only C. atratum individuals that overlapped in size (shell weight) with $P$. criniticornis were used in this analysis. The relationships $(y=\mathrm{a}$ $+b x$ ) between the shell weight and the dry weights of the gastropods (soft parts only) and hermit crabs (in optimal shells) were calculated and then compared through ANCOVA.

\section{RESULTS}

\section{Consumption rate and critical size (Questions 1 and 2)}

The 4 predator species showed different consumption rates of Cerithium atratum (ANOVA, $F=4.009$, $\mathrm{df}=3, \mathrm{p}=0.011$, Fig. 2), but the only significant pairwise difference was found between Menippe nodifrons and Panopeus occidentalis. The high variability within treatments (predator species) did not allow clear comparisons among them (see Fig. 2). Crab weight was another source of variability in the analysis. ANCOVA revealed a non-significant influence of predator species and a significant effect of crab weight in consumption rate (ANCOVA; treatment effect: crab predator species, $F=0.514, \mathrm{df}=3, \mathrm{p}=0.674$; covariate effect: crab weight, $F=6.437$, $\mathrm{df}=1, \mathrm{p}=0.013$ ).

A variable number of unsuccessful predatory attempts was recorded for the 4 shell-breaking crabs (ANOVA; $F=5.367, \mathrm{df}=3, \mathrm{p}=0.002$ ). Lower values were recorded for the xanthid crabs Panopeus occidentalis, Eriphia gonagra, and Menippe nodifrons, although the higher values presented by the blue crab Callinectes danae did not differ significantly from those of E. gonagra. As opposed to the mean number of gastropods consumed, the mean number of unsuccessful attempts depended more on crab species than on crab weight (ANCOVA; treatment effect: crab predator species, $F=4.402, \mathrm{df}=3, \mathrm{p}=0.007$; covariate effect: crab weight, $F=0.358, \mathrm{df}=1, \mathrm{p}=0.552$ ). The successful predation rate (successful attempts/successful + unsuccessful attempts) also depended on crab species (ANOVA; $F=4.444 ; \mathrm{df}=3, \mathrm{p}=0.008$ ). However, when crab weight was taken into account, neither crab species nor crab weight explained the variation in the rate of successful predation among crab species (ANCOVA; treatment effect: crab predator species, $F=$ 2.617, df $=3, \mathrm{p}=0.059$; covariate effect: crab weight, $F=0.136, \mathrm{df}=1, \mathrm{p}=0.714$ )

Comparison of prey size among crab species revealed that all predator species were able to consume prey of almost all the size classes used in the experiment (except Panopeus occidentalis) and that the mean prey size did not differ among predators (ANOVA; $F=0.555, \mathrm{df}=3, \mathrm{p}=0.646$, see Table 1 ). As a consequence, the critical size of Cerithium atratum could not be determined for and compared among these predator species.

As in the experiments with Cerithium atratum, high
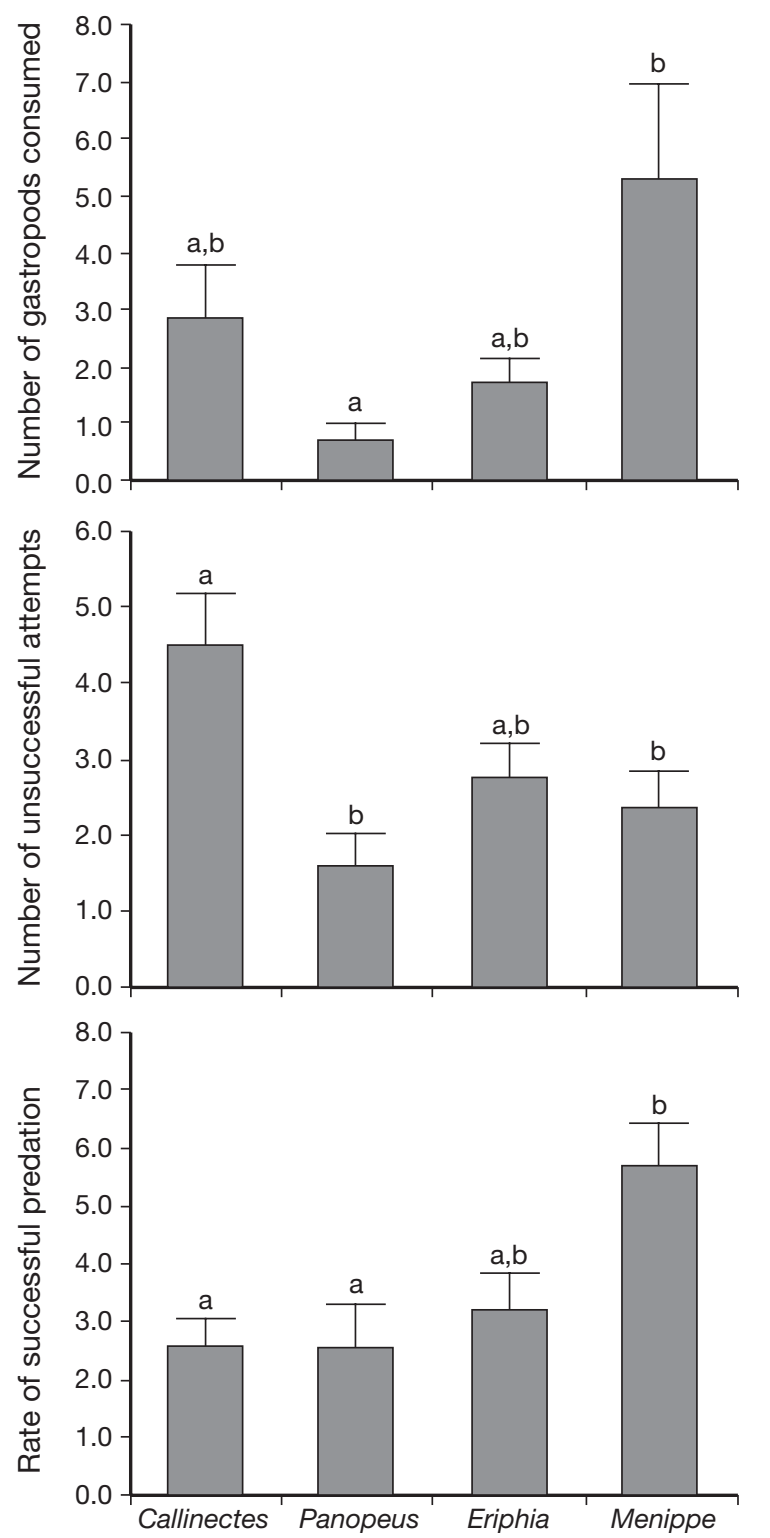

Fig. 2. Cerithium atratum preyed upon by Callinectes danae, Panopeus occidentalis, Eriphia gonagra, and Menippe nodifrons. Comparison of the mean $(+\mathrm{SE})$ number of gastropods consumed (consumption rate), mean $(+\mathrm{SE})$ number of unsuccessful attempts, and mean $(+\mathrm{SE})$ rate of successful predation (successful attempts/successful + unsuccessful attempts) during 3 subsequent days. Letters above SE bars indicate the result of the Tukey's HSD test for multiple comparisons, different letters indicating a significant difference 
Table 1. Cerithium atratum. Comparison of the sizes (shell length, $\mathrm{mm}$ ) of the largest individuals peeled and crushed by the 4 predator species. Only predator individuals that preyed through both peeling and crushing were used in this analysis. The total number of prey consumed by all tested predator individuals and the mean prey size $( \pm \mathrm{SD})$ are shown in brackets for each predator species

\begin{tabular}{|lcc|}
\hline $\begin{array}{l}\text { Predator species } \\
\text { and weight }(\mathrm{g})\end{array}$ & $\begin{array}{c}\text { Largest peeled } \\
(\mathrm{mm})\end{array}$ & $\begin{array}{c}\text { Largest crushed } \\
(\mathrm{mm})\end{array}$ \\
\hline \multicolumn{3}{c}{ Callinectes danae $(\mathrm{N}=151,23.93 \pm 4.19 \mathrm{~mm})$} \\
85.4 & 27.85 & 28.20 \\
89.0 & 27.80 & 18.70 \\
62.9 & 32.80 & 20.20 \\
77.3 & 28.85 & 25.85 \\
73.1 & 30.55 & 29.50 \\
39.3 & 30.60 & 25.45 \\
Panopeus occidentalis $(\mathrm{N}=46,23.37 \pm 4.34$ & $\mathrm{mm})$ \\
17.0 & 27.60 & 19.55 \\
Eriphia gonagra $(\mathrm{N}=90,24.67 \pm 4.30 \mathrm{~mm})$ & \\
23.0 & 27.60 & 22.20 \\
25.2 & 28.75 & 23.30 \\
46.2 & 32.00 & 26.40 \\
24.0 & 28.85 & 23.20 \\
19.4 & 23.40 & 29.20 \\
24.9 & 24.15 & 26.20 \\
Menippe nodifrons $(\mathrm{N}=148,24.45 \pm 4.31 \mathrm{~mm})$ \\
99.5 & 32.10 & 26.20 \\
70.1 & 29.40 & 30.45 \\
\multicolumn{4}{|c}{} \\
\hline
\end{tabular}

variability in the number of Stramonita haemastoma, Tegula viridula, and Morula nodulosa consumed was recorded for the predator species Menippe nodifrons and Callinectes danae. High variation was also recorded among the gastropod species tested. $M$. nodulosa was only preyed upon by $M$. nodifrons, and at a markedly lower rate $\left(0.21 \pm 0.31\right.$ ind. $\left.\mathrm{d}^{-1}\right)$ than $S$. haemastoma (paired $t$-test: $t=5.04, \mathrm{df}=8, \mathrm{p}=0.001$ ) and $T$. viridula $(t=3.38$, df $=8, \mathrm{p}<0.001)$. The consumption rate of $C$. danae and $M$. nodifrons on $S$. haemastoma $\left(1.78 \pm 1.59\right.$ ind. $\mathrm{d}^{-1}$ and $0.91 \pm 0.34$ ind. $\mathrm{d}^{-1}$, respectively) and $T$. viridula $\left(0.13 \pm 0.16\right.$ ind. $\mathrm{d}^{-1}$ and $0.39 \pm 0.38$ ind. $\mathrm{d}^{-1}$, respectively) did not vary between predators (Student's $t$-test; $C$. danae: $t=1.61$, $\mathrm{df}=16, \mathrm{p}=0.128 ; M$. nodifrons: $t=1.93, \mathrm{df}=16, \mathrm{p}=$ 0.072), but both crabs preyed proportionally more upon $S$. haemastoma than upon $T$. viridula (paired $t$ test; $C$. danae: $t=3.04, \mathrm{df}=8, \mathrm{p}=0.016 ; M$. nodifrons: $t=3.36$, df $=8, \mathrm{p}=0.001$ ).

Menippe nodifrons showed a non-significant tendency to prey (independent of predatory strategy) upon larger-sized Stramonita haemastoma and Tegula viridula individuals than Callinectes danae $(t=-1.69$, $\mathrm{df}=15, \mathrm{p}=0.112 ; t=-1.57, \mathrm{df}=11, \mathrm{p}=0.143$; see Table 4). However, these 2 crabs were not able to prey upon the largest individuals of the 3 gastropod species offered to them. The critical sizes (dry weight of soft parts) were also compared among the 3 gastropods preyed upon by $M$. nodifrons. The critical sizes of Morula nodulosa and $T$. viridula were similar (paired $t$-test; $t=3.06, \mathrm{df}=3, \mathrm{p}=0.06$ ), although a slight tendency to present lower values was registered for $M$. nodulosa (Table 2). S. haemastoma had a higher critical size than both $T$. viridula $(t=4.77, \mathrm{df}=6, \mathrm{p}=0.003)$ and $M$. nodulosa $(t=5.56, \mathrm{df}=3, \mathrm{p}=0.012)$.

\section{Gastropod investment in architectural defense (Question 3)}

Strong linear relationships were recorded between dry weight of soft parts and shell weight for all gastropod species (Fig. 3). ANCOVA rejected the null hypothesis of similarity among the slopes of the regression models and also showed a significant variation in the $y$-intercept values (ANCOVA; $y$-intercept: $F=$ 5.888, df $=3$, p < 0.001; slope: $F=209.300$, df $=3$, p < 0.001). The Tukey-type multiple comparison test revealed a descending order for regression coefficients ( $\mathrm{p}<0.05$ for all comparisons): Morula nodulosa $>$ Cerithium atratum > Tegula viridula $>$ Stramonita haemastoma. This indicates that individuals of the species in the upper limit (M. nodulosa) invested more in shell material than did individuals of species in the subsequent descending order.

\section{Predatory strategy (Question 4)}

Table 2. Stramonita haemastoma, Morula nodulosa, and Tegula viridula. Comparison of the critical sizes (dry weights of shells and soft parts, g) of the largest crushed individuals consumed by Menippe nodifrons in the laboratory. Only predator individuals that preyed on at least 2 gastropod species are included

\begin{tabular}{|c|c|c|c|c|c|c|}
\hline \multirow{2}{*}{$\begin{array}{l}\text { M. nodifrons } \\
\text { weight }(\mathrm{g})\end{array}$} & \multicolumn{2}{|c|}{ Stramonita haemastoma } & \multicolumn{2}{|c|}{ Morula nodulosa } & \multicolumn{2}{|c|}{ Tequla viridula } \\
\hline & Shell weight & Flesh weight & Shell weight & Flesh weight & Shell weight & Flesh weight \\
\hline 122.0 & 4.966 & 0.262 & 0.954 & 0.030 & 3.030 & 0.166 \\
\hline 105.8 & 1.425 & 0.070 & & & 0.191 & 0.009 \\
\hline 295.1 & 7.092 & 0.381 & 0.948 & 0.030 & 4.342 & 0.244 \\
\hline 76.0 & 2.677 & 0.137 & & & 0.436 & 0.021 \\
\hline 149.2 & 3.521 & 0.182 & 0.782 & 0.024 & 3.226 & 0.178 \\
\hline 87.7 & 2.713 & 0.139 & & & 0.436 & 0.021 \\
\hline 82.2 & 3.862 & 0.201 & 0.273 & 0.008 & 0.436 & 0.021 \\
\hline
\end{tabular}




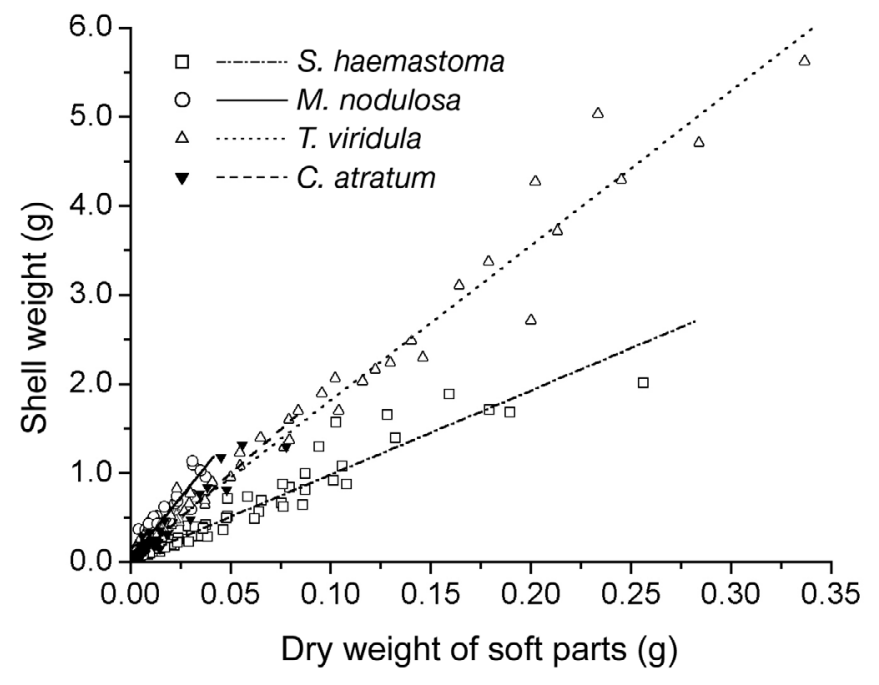

Fig. 3. Stramonita haemastoma, Morula nodulosa, Tegula viridula, and Cerithium atratum. Linear regressions between dry weight of soft parts $(\mathrm{g})$ and shell weight $(\mathrm{g})$ ( $S$. haemastoma, $y=0.042+9.458 x, \mathrm{~N}=64, \mathrm{r}^{2}=0.917, \mathrm{p}<0.001$; M. nodulosa, $y=0.041+27.769 x, \mathrm{~N}=77, \mathrm{r}^{2}=0.909, \mathrm{p}<0.001$; T. viridula, $y=0.088+17.373 x, \mathrm{~N}=91, \mathrm{r}^{2}=0.979, \mathrm{p}<0.001$; C. atratum, $y=0.009+19.885 x, \mathrm{~N}=139, \mathrm{r}^{2}=0.946, \mathrm{p}<0.001$ )

In addition to the differences in the consumption rate, number of unsuccessful attempts, and rate of successful predation among species described above, the 4 predator species used different strategies to prey upon the gastropod Cerithium atratum (Table 3). Menippe nodifrons almost exclusively 'crushed' its prey, while Callinectes danae and Eriphia gonagra showed an equilibrium between crushing and peeling. Panopeus occidentalis tended to use peeling more frequently than crushing as a predatory strategy. Perforation of the body whorl of the gastropod shell was a less frequent but successful predatory strategy employed by $M$. nodifrons and C. danae. Perforations in the body

Table 3. Cerithium atratum. Number of shells showing 4 types of damage resulting from successful (prey $=$ dead) or unsuccessful (prey = alive) attacks on $C$. atratum by 4 crab predators

\begin{tabular}{|c|c|c|c|c|c|c|c|c|}
\hline \multirow[t]{2}{*}{ Predator } & \multicolumn{2}{|c|}{ Crushed } & \multicolumn{2}{|c|}{ Peeled } & \multicolumn{2}{|c|}{ Apex } & \multicolumn{2}{|c|}{ Perforation } \\
\hline & Dead & Alive & Dead & Alive & Dead & Alive & Dead & Alive \\
\hline $\begin{array}{l}\text { Callinectes } \\
\text { danae }\end{array}$ & 32 & 0 & 28 & 89 & 0 & 0 & 3 & 2 \\
\hline $\begin{array}{l}\text { Panopeus } \\
\text { occidentalis }\end{array}$ & 4 & 0 & 10 & 31 & 0 & 1 & 0 & 0 \\
\hline $\begin{array}{l}\text { Eriphia } \\
\text { gonagra }\end{array}$ & 19 & 0 & 15 & 52 & 0 & 0 & 0 & 1 \\
\hline $\begin{array}{l}\text { Menippe } \\
\text { nodifrons }\end{array}$ & 101 & 0 & 4 & 41 & 0 & 2 & 1 & 1 \\
\hline
\end{tabular}

whorl were also frequently observed 1 or $2 \mathrm{~d}$ before a given shell was crushed. Crushing was always associated with gastropod death, while peeling attempts showed significantly higher prey survivorship with all predators ( 76 to $91 \%$ ). Apex breakage was infrequent in the experiment and never caused gastropod death. In some cases, the gastropod was preyed on and the shell left intact. This occurred only when shells were very large in relation to the crabs. In such cases, as well as in successful peeling attempts, only the anterior part of the gastropod was consumed. In descending order, crushing, peeling, and perforations in the body whorl were the main predatory strategies employed by the predators studied. Fig. 4 illustrates the damage caused by different predatory strategies to the shells of $C$. atratum. Crushing may have 2 outcomes: (1) the shells may be entirely broken with only a tiny portion of the shell apex remaining intact (Fig. 4f), and (2) the apex and high spires of the shells may be removed and the aperture sometimes also peeled (Fig. 4e).

The maximum sizes of shells peeled and crushed by each individual predator are shown in Table 1. A comparison of predatory strategies revealed that shells crushed by Callinectes danae and Eriphia gonagra were on average smaller than those that were peeled (Student's $t$-test; $t=-4.25, \mathrm{df}=57, \mathrm{p}<0.001$ and $t=$ -2.84 , df $=32, p=0.009$, respectively). Such differences could not be verified for Panopeus occidentalis and Menippe nodifrons, but the same tendency persisted.

Different predatory strategies were also used by Menippe nodifrons and Callinectes danae to prey upon the gastropods Stramonita haemastoma, Tegula viridula, and Morula nodulosa (Fig. 5). M. nodifrons generally crushed the shells, while peeling was more common for C. danae. M. nodulosa and $T$. viridula shells were mainly crushed by $M$. nodifrons, while both crushing and peeling were used by $C$. danae to prey upon $T$. viridula. Most of the peeled shells had only small pieces of their apertures removed by the crab claw, indicating that predators break only the amount necessary to reach the prey's soft parts. The opercula of almost all peeled individuals were destroyed. This feature was more evident with $C$. danae, which introduced its slender, sharp claws into the shell aperture to damage the gastropod's operculum and consume its anterior part. In some cases, crabs were able to consume the prey without breaking the shells (Fig. 5). This occurred at a lower frequency than other predatory strategies and only when shells were very large in relation to 


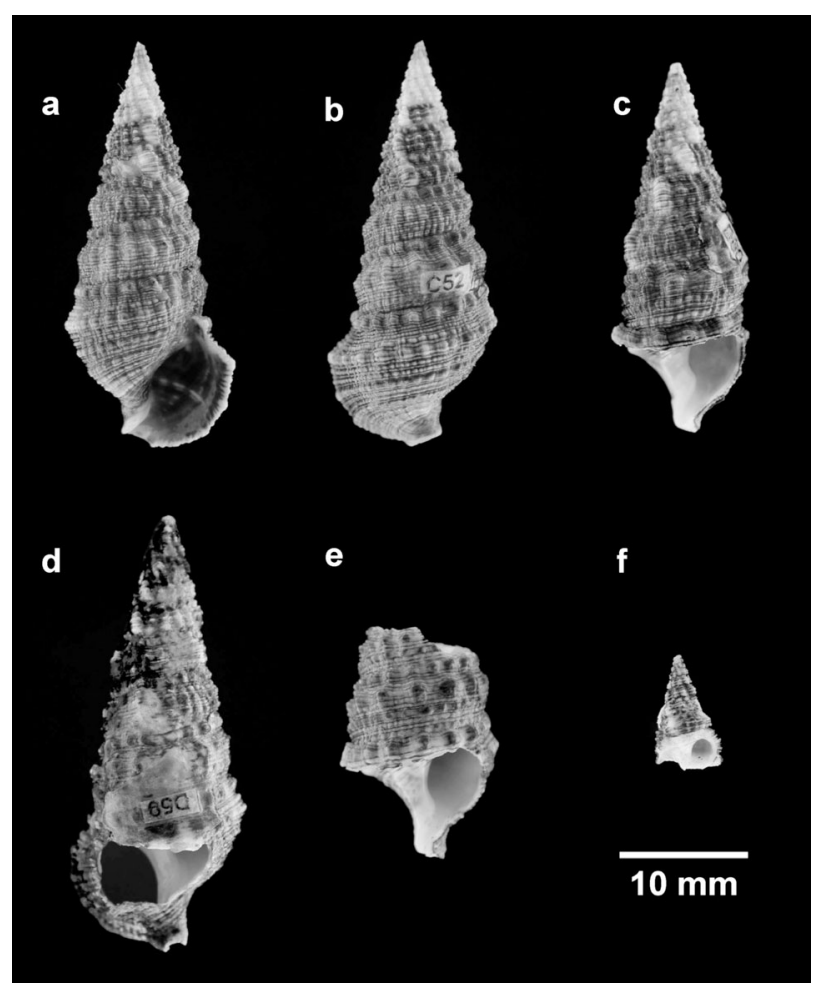

Fig. 4. Cerithium atratum. Types of damage caused by successful predatory attempts to shells in the laboratory. $(\mathrm{a}, \mathrm{b})$ intact shell; $(\mathrm{c})$ peeled; $(\mathrm{d})$ perforation in the body whorl (e) crushed (peeled and without apex); (f) crushed (shell apex only)

the crab, due to the easy introduction of the claw into the shell aperture. These 3 predatory strategies (crushing, peeling, and intact) were used by the crabs to prey upon $S$. haemastoma individuals of different sizes (Table 4). Relatively smaller gastropods were crushed, while peeling was used to prey upon relatively larger individuals. The largest consumed gastropods were generally preyed on without injuries to their shells.

When critical size (shell length) of Stramonita haemastoma was compared between predators taking predatory strategy into account, $M$. nodifrons was able to crush larger S. haemastoma individuals than Callinectes danae (Student's $t$-test; $t=-2.75$, df $=9, \mathrm{p}=$ 0.026). M. nodifrons also showed a higher tendency to prey on larger-sized $S$. haemastoma through both peeling and without causing damage (intact shells) than $C$. danae (peeled: $t=-1.94, \mathrm{df}=13, \mathrm{p}=0.074$; intact: $t=-1.37$, df $=7, \mathrm{p}=0.214)$. This analysis, separated by predatory strategy, could not be employed to $M$. nodulosa and $T$. viridula. The weight of both $C$. danae and $M$. nodi- frons and the largest consumed (all strategies pooled), largest peeled, largest crushed, and largest intact $S$. haemastoma individual were not significantly correlated (Pearson correlation; $\mathrm{p}>0.05$ for all comparisons), indicating that critical sizes are not a function of predator size.

\section{Damage to Cerithium atratum shells: experiments versus those used by Pagurus criniticornis in the field (Question 5)}

Analysis of a field sample revealed that $74 \%$ of hermit crab Pagurus criniticornis individuals used Cerithium atratum shells in the Araçá region. Utilization of intact shells of this species was common (31.6\% of individuals) but they were frequently damaged (Fig. 6). Peeled shells (see Fig. 4c) were most commonly used by the hermit crabs, followed by peeled shells lacking both apex and high spires (see Fig. 4e). A high proportion of this hermit crab population used only tiny shell apexes (Fig. 4f). Perforations in the gastropod body whorl (Fig. 4d) were more common than shells without an apex. Damage caused by other predators, such as drilling gastropods, was less frequent than other types, but represented almost $10 \%$ of the damaged shells used by the hermit crabs.

\section{Predation by Menippe nodifrons: \\ Pagurus criniticornis versus Cerithium atratum (Question 6)}

This experiment tested the preference of Menippe nodifrons for the gastropod Cerithium atratum or the hermit crab Pagurus criniticornis using $C$. atratum shells of preferred size (optimal shells). M. nodifrons

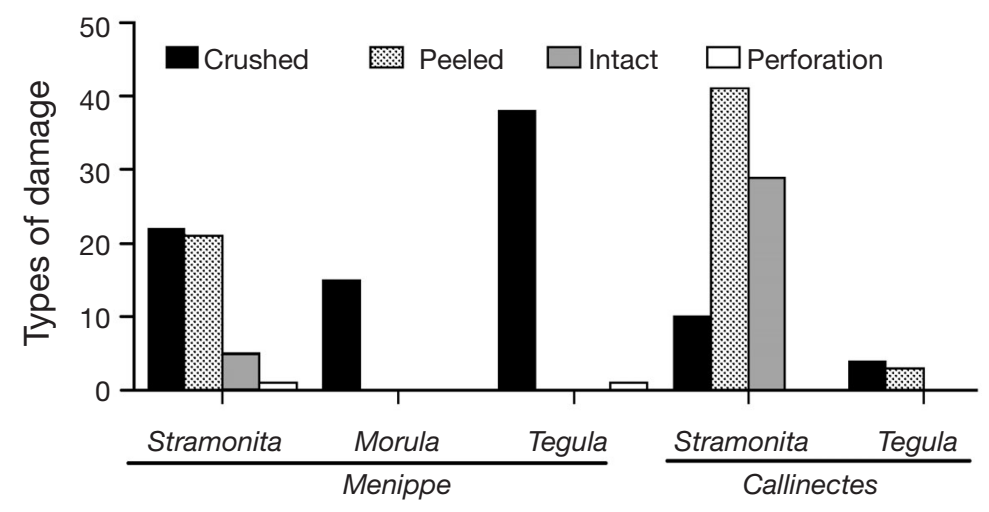

Fig. 5. Stramonita haemastoma, Morula nodulosa, and Tegula viridula. Types of damage caused to prey (consumed + not consumed) by both Menippe nodifrons and Callinectes danae in the laboratory. A perforation is damage caused to the body whorl of the gastropod. Intact shells are those that were consumed without damage to the shell 
Table 4. Stramonita haemastoma, Morula nodulosa, and Tegula viridula. Comparison of the critical sizes (shell length, mm) of the largest peeled, largest crushed and largest intact individuals consumed by Callinectes danae and Menippe nodifrons in the laboratory. Only individuals that preyed on at least 1 gastropod are included

\begin{tabular}{|c|c|c|c|c|c|c|c|c|c|}
\hline \multirow{2}{*}{$\begin{array}{l}\text { Predator species } \\
\text { and weight }(\mathrm{g})\end{array}$} & \multicolumn{3}{|c|}{ - S. haemastoma } & \multirow[b]{2}{*}{ Peeled } & \multirow{2}{*}{$\begin{array}{l}\text { M. nodulosa } \\
\text { Crushed }\end{array}$} & \multirow{2}{*}{$\overline{\text { Intact }}$} & \multirow[b]{2}{*}{ Peeled } & \multirow{2}{*}{$\begin{array}{l}\text { T. viridula } \\
\text { Crushed }\end{array}$} & \multirow[b]{2}{*}{ Intact } \\
\hline & Peeled & Crushed & Intact & & & & & & \\
\hline \multicolumn{10}{|l|}{ C. danae } \\
\hline 101.4 & 27.35 & 23.15 & & & & & & 7.10 & \\
\hline 63.3 & 22.45 & & & & & & & & \\
\hline 43.3 & 25.85 & 11.45 & 31.30 & & & & & & \\
\hline 80.3 & 27.20 & 20.70 & & & & & & & \\
\hline 58.4 & 21.80 & 17.05 & 29.50 & & & & & 3.80 & \\
\hline 75.3 & 24.70 & & 27.00 & & & & 5.80 & & \\
\hline 65.2 & 26.15 & & 36.50 & & & & 6.00 & & \\
\hline 37.4 & 22.80 & & 31.35 & & & & 4.20 & & \\
\hline \multicolumn{10}{|l|}{ M. nodifrons } \\
\hline 122.0 & 26.40 & 28.65 & & & 19.70 & & & 14.30 & \\
\hline 105.8 & & 19.45 & 37.80 & & & & & 4.25 & \\
\hline 295.1 & & 32.00 & 44.65 & & 19.65 & & & 16.75 & \\
\hline 76.0 & 26.90 & 23.65 & & & & & & 6.10 & \\
\hline 149.2 & 25.60 & 25.75 & 35.90 & & 18.30 & & & 14.70 & \\
\hline 87.7 & 32.60 & 23.75 & & & & & & 6.10 & \\
\hline 82.2 & 44.75 & 26.50 & & & 12.40 & & & 6.10 & \\
\hline 17.2 & 28.15 & & & & & & & & \\
\hline 39.8 & 24.65 & & 26.55 & & & & & 4.85 & \\
\hline
\end{tabular}

showed a significant preference for the gastropod (18 out of 24 replicates) over the hermit crab (6 out of 24 replicates; $G=6.28$, df $=1, \mathrm{p}<0.05$ ).

Analysis of the relationship between dry weight of soft parts of the gastropods and hermit crabs (in optimal shells) and shell weight revealed that the data for Pagurus criniticornis were more dispersed $(y=0.078+$ $\left.9.026 x, \mathrm{~N}=105, \mathrm{r}^{2}=0.961, \mathrm{p}<0.001\right)(y=0.017+$ $\left.19.613 x, N=82, r^{2}=0.968, p<0.001\right)$ and showed a lower increase in shell weight in relation to dry weight of soft parts than those for Cerithium atratum

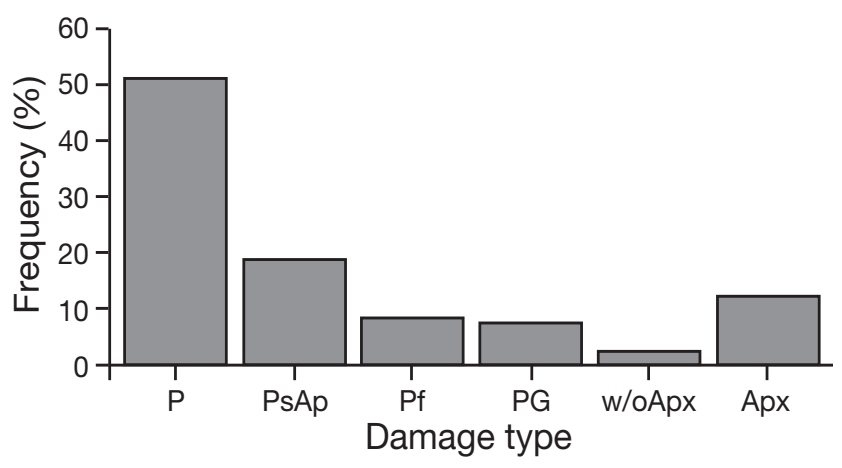

Fig. 6. Pagurus criniticornis using Cerithium atratum shells. Frequency of the types of shell damage recorded in the Araçá region, São Sebastião Channel, SE Brazil. P: peeled; PsAp: peeled and without both apex and high spires; Pf: perforation in shell body whorl; PG: perforation caused by a gastropod predator; w/oApx: without apex; Apx: only apex present
(ANCOVA; $y$-intercept: $F=7.384, \mathrm{df}=1, \mathrm{p}=0.007$; slope: $F=118.762, \mathrm{df}=1, \mathrm{p}<0.001$; Fig. 7). This means that $P$. criniticornis offers proportionally more biomass than $C$. atratum in relation to a similar predation effort (similar shell weights) and that this difference increases with shell size.

\section{DISCUSSION}

Differences among crab species to predation can be attributed to their specific differences in size (weight), as there was no variation in the mean consumption rate of gastropods and in the mean number of successful attempts among treatments (predator species) when crab weight was introduced into the linear model as a covariate. These results suggest that the 4 tested predator species have similar abilities to prey upon Cerithium atratum. The only difference recorded among species independent of their specific weight was in the number of unsuccessful attempts, which was higher for Callinectes danae. Thus, despite the higher absolute number of prey consumed by this species, its rate of successful predation upon C. atratum was lower than those of Menippe nodifrons and Panopeus occidentalis. This suggests better adaptation of xanthid crabs, such as $M$. nodifrons, compared to that of the portunid blue crabs, such as C. danae, as shell-breaking predators, as argued by Vermeij (1978) and Yamada \& Boulding (1998). 


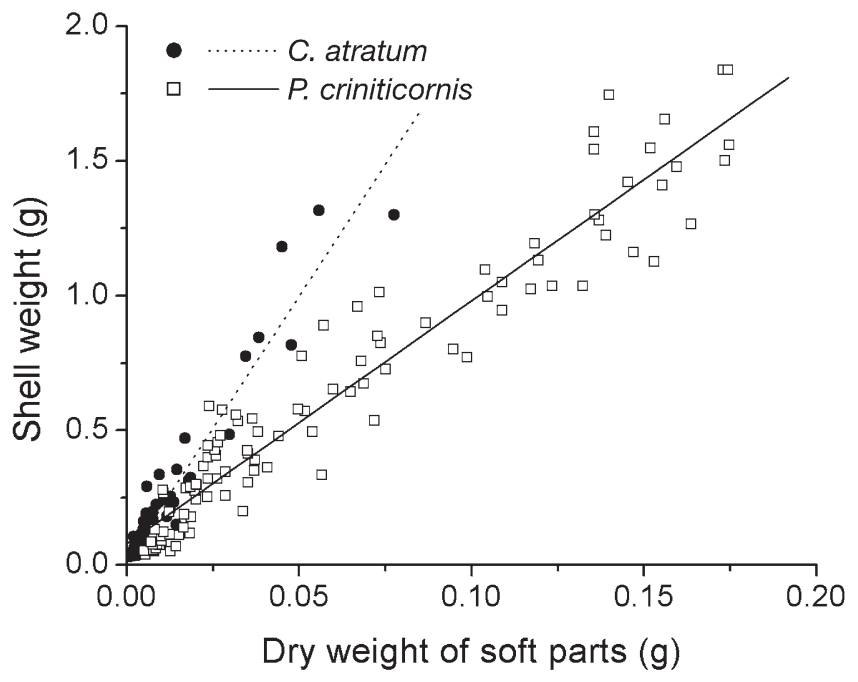

Fig. 7. Cerithium atratum and Pagurus criniticornis. Linear regressions between dry weight of soft parts $(g)$ and shell weight $(\mathrm{g})$ of the gastropod C. atratum and of the hermit crab $P$. criniticornis in optimally sized C. atratum shells. Only C. atratum individuals that overlapped in size (shell weight) with $P$. criniticornis were used in this analysis

A critical size could not be determined for Cerithium atratum because all predator species (except Panopeus occidentalis) were able to prey upon the entire size range tested. This indicates that this species and, consequently, the hermit crabs that use their shells do not attain a size refuge from predation in the study area. The effect each predator species has in nature depends on their abundance and microhabitat overlap with their prey. There are no estimates of the relative abundance of these crabs in the Araçá region, but a microhabitat separation is evident. Callinectes danae occurs almost exclusively in muddy substrates, while the 3 other species are associated with cobbles and highly heterogeneous rocky shores. The hermit crabs in this region also show a marked habitat partitioning, with Pagurus criniticornis occurring predominantly in mud, and Clibanarius antillensis, C. sclopetarius, and C. vittatus in coarse sand, gravel, and hard-bottom substrates (Turra et al. 2000). This feature may make these hermit crab species accessible to different predators.

Differential architectural defenses of gastropods may explain the pattern of shell use (Bertness \& Cunningham 1981) and selection (Borjesson \& Szelistowski 1989) by hermit crabs. There are various shell characteristics that reduce predation risk, such as thickened walls, narrow shell apertures, axial shell sculptures, short spires (Vermeij 1978, Bertness \& Cunningham 1981, Lively 1988) and, in the case of hermit crabs, depth into which the crabs can withdraw (Lively 1988). The 3 most common gastropod species in intertidal rocky shores in SE Brazil invest in shell architectural defenses differently (Morula nodulosa > Tegula viridula > Stramonita haemastoma), i.e. weight of shell material in relation to dry weight of soft parts. M. nodulosa shells have determinate growth, narrow and thickened apertures, and axial ribbing (Magalhães 2000), while T. viridula has a lowspire shell. The elongated shells of $S$. haemastoma have large apertures through which predators can introduce their claws. In addition, the energy gain in relation to shell weight (crab effort) and critical size are higher for $S$. haemastoma. Such arguments explain the differences in the rate of consumption by Menippe nodifrons and Callinectes danae among these 3 gastropod species $(S$. haemastoma $>T$. viridula $>M$. nodulosa and $S$. haemastoma $>T$. viridula, respectively). However, as Bertness (1981c) has pointed out, there are conflicting advantages in relation to shell use by hermit crabs. Utilization of $M$. nodulosa shells may prevent predation, due to the lower critical size of this species in relation to others, but it may also restrict hermit crab growth, as this gastropod is on average smaller than $T$. viridula and S. haemastoma, and, as a consequence, it may influence crab morphology (Markham 1968, Fotheringham 1976b, Blackstone 1985, Turra \& Leite 2003). Utilization of relatively small-sized shells may also reduce fecundity (Fotheringham 1976a), as egg number is directly related to crab size (Turra \& Leite 1999, 2001). As a result, larger individuals are expected to use/prefer $T$. viridula or $S$. haemastoma shells. In areas with lower predation pressure, S. haemastoma would be preferred over $T$. viridula, although relatively heavier shells (such as $T$. viridula) may be preferred under high hydrodynamic conditions (see Hahn 1998).

High values of mortality have been estimated for gastropods in nature (Spight 1977, Bertness 1981b, Wilber \& Herrnkind 1984) and positive relationships have been established between gastropod mortality rate and shell use by hermit crabs (Wilber \& Herrnkind 1984). Bertness \& Cunningham (1981) estimated that up to $63 \%$ of the shells used by hermit crabs have damage inflicted on them by predation attempts. For Pagurus criniticornis, up to $68 \%$ of the Cerithium atratum shells (74\% of all shells used) have damage that indicates predation on previous shell occupants, whether gastropods or hermit crabs, thus reinforcing the important role of shell-breaking predation in making new shells available to the hermit crabs.

Predatory strategy was demonstrated to depend on predator and prey species, and on their relative sizes. 
In general, relatively small shells are crushed while relatively larger ones are peeled, as has also been shown by Bertness \& Cunningham (1981). Largeaperture shells (Stramonita haemastoma) were more frequently preyed upon through the aperture than small-aperture ones (Tegula viridula, Morula nodulosa, and Cerithium atratum). The use of different predatory strategies to prey on gastropods ( $S$. haemastoma) of different sizes causes critical shell size to be independent from predator size (non-significant correlations). The different species of shell-breaking predators and predatory strategies produce types of damage to gastropod shells (Bertness \& Cunningham 1981, McLean 1983, Lau 1987) that allow their future use by hermit crabs. Menippe nodifrons generally crushed $C$. atratum shells, producing empty shells with peeled apertures lacking both apex and high spires (see Fig. 4e) which are used by medium-sized hermit crabs. Severe crushing also produced tiny shell apices, used only by recruits and small-sized individuals. Generally, large hermit crabs used peeled shells, which were likely to be a consequence of predation events by Callinectes danae and M. nodifrons, over relatively larger shells in nature. Crushing of $S$. haemastoma, $T$. viridula, and $M$. nodulosa shells only produced shell fragments that could not be used by hermit crabs, as has also been reported for Nerita funiculata (Bertness \& Cunningham 1981). Only the relatively larger peeled or intact shells of the 2 former species could still be used. Utilization of intact shells by hermit crabs may be a consequence of predatory events involving crabs and their relatively large-sized prey (see also Vermeij 1978), but may also be a consequence of stochastic mortality pulses, such as the desiccation deaths of $C$. atratum recorded during low tides in summer 2001 (A. Turra unpubl. data).

Despite hermit crabs presenting behavioral antipredator strategies (Bertness 1981b, Kuhlmann 1992, Scarratt \& Godin 1992, Hazlett \& Rittschof 2000), they are as susceptible as living gastropods to shell-breaking predators. In situ experiments have shown that predation on hermit crabs can be as high as $100 \%$ in some situations, depending on gastropod species, shore height, and season (Borjesson \& Szelistowski 1989, but see Kuhlmann 1992). Shell epibionts may aid hermit crab protection against predators (Ross 1971, Partdrige 1980, Turra 2003, but see Buckley \& Ebersole 1994) but, in some coastal areas, hermit crabs may use shells in poorer condition (physical damage) than those of the snails (A. Turra unpubl. data), which can make them more vulnerable to predation (Vance 1972b, McClintock 1985, LaBarbera \& Merz 1992). In addition, low shell adequacy and condition, which is also common to most intertidal species
(Vance 1972a, Bertness 1980, Gilchrist \& Abele 1984, Barnes 1999, Turra 2003), may also increase hermit crab vulnerability to predation (Angel 2000) in relation to gastropods. As a consequence, the preference of Menippe nodifrons for Cerithium atratum in the laboratory may not occur in nature due to shell constraints. Although Pagurus criniticornis provided more biomass to predators than $C$. atratum, the preference of $M$. nodifrons for the gastropod may also be a consequence of the lower mobility of this gastropod in relation to the hermit crab. Conversely, such a difference may also be explained by the poorer energy content of hermit crabs, since their hard exoskeletons are not digested by the predators. However, the predators may take advantage of almost all parts of the gastropod. The preference of $M$. nodifrons for the gastropod over the hermit crab may also indicate the evolutionary stability of shell-use behavior in hermit crabs. In turn, the preference of shell-breaking crabs may be dependent on gastropod or predator species, indicating that predation pressure on hermit crabs may be highly variable in nature. Rossi \& Parisi (1973) showed that the preference of Eriphia verrucosa for snails or hermit crabs depended on the gastropod species, but that it was stronger on average for hermit crabs. On the other hand, Bertness \& Cunningham (1981) demonstrated that the crabs Ozius verreauxii and Eriphia squamata showed no preference between gastropods and hermit crabs.

In conclusion, predation on gastropods by shellbreaking crabs was demonstrated to have an important role in shell availability to hermit crabs. The predation pressure on gastropods was demonstrated to be dependent on predator species (see also Bertness \& Cunningham 1981) and size, species-specific gastropod architectural defenses (see also Vermeij 1978, Bertness \& Cunningham 1981, Borjesson \& Szelistowski 1989, but see Kuhlmann 1992), and on the relative predator-prey size (see also Bertness \& Cunningham 1981, but see Kuhlmann 1992), which determined the predatory strategy and the damage inflicted on the shells, making shells available to hermit crabs of different sizes, from recruits to adults.

Acknowledgements. We would like to thank the Fundação de Amparo à Pesquisa do Estado de São Paulo (FAPESP, Proc. No. 98/00483-0) and CAPES for scholarship grants to A.T. FAEP partially funded this project and the Centro de Biologia Marinha of Universidade de São Paulo (CEBIMarUSP) furnished the laboratory to conduct this research. Thanks are expressed to A. M. S. P. Vanin, R. M. Shimizu, T. M. Lewinsohn, C. A. Magalhães, and 4 anonymous referees for comments on the manuscript, and to P. M. Sikar for English revision. 


\section{LITERATURE CITED}

Angel JE (2000) Effects of shell fit on the biology of the hermit crab Pagurus longicarpus (Say). J Exp Mar Biol Ecol 243: 169-184

Barnes DKA (1999) Ecology of tropical hermit crabs at Quirimba Island, Mozambique: shell characteristics and utilisation. Mar Ecol Prog Ser 183:241-251

Bertness MD (1980) Shell preference and utilization patterns in littoral hermit crabs of the Bay of Panama. J Exp Mar Biol Ecol 48:1-16

Bertness MD (1981a) The influence of shell-type on hermit crab growth rate and clutch size (Decapoda, Anomura). Crustaceana 40:197-205

Bertness MD (1981b) Predation, physical stress, and the organization of a tropical rocky intertidal hermit crab community. Ecology 62:411-425

Bertness MD (1981c) Conflicting advantages in resource utilization: the hermit crab housing dilemma. Am Nat 118: 432-437

Bertness MD, Cunningham C (1981) Crab shell-crushing predation and gastropod architectural defense. J Exp Mar Biol Ecol 50:213-230

Bertness MD, Garrity SD, Levings SC (1981) Predation pressure and gastropod foraging: a tropical-temperate comparison. Evolution 35:995-1007

Blackstone NW (1985) The effects of shell size and shape on growth and form in the hermit crab Pagurus longicarpus. Biol Bull (Woods Hole) 168:75-90

Borjesson DL, Szelistowski WA (1989) Shell selection, utilization and predation in the hermit crab Clibanarius panamensis Stimpson in a tropical mangrove estuary. J Exp Mar Biol Ecol 133:213-228

Buckley WJ, Ebersole JP (1994) Symbiotic organisms increase the vulnerability of a hermit crab to predation. J Exp Mar Biol Ecol 182:49-64

Childress JR (1972) Behavioral ecology and fitness theory in a tropical hermit crab. Ecology 53:960-964

Cortez T, Castro BG, Guerra A (1998) Drilling behavior of Octopus mimus Gould. J Exp Mar Biol Ecol 224:193-203

Fotheringham N (1976a). Effects of shell stress on the growth of hermit crabs. J Exp Mar Biol Ecol 23:299-305

Fotheringham N (1976b) Population consequences of shell utilization by hermit crabs. Ecology 57:570-578

Gibran FZ, Castro RMC (1999) Activity, feeding behavior and diet of Ogcocephalus vespertilio in southern west Atlantic. J Fish Biol 55:588-595

Gilchrist S, Abele LG (1984) Effects of sampling method on the estimation of population parameters in hermit crabs. J Crustac Biol 4:645-654

Hahn DR (1998) Hermit crab shell use patterns: response to previous shell experience and to water flow. J Exp Mar Biol Ecol 228:35-51

Hazlett BA, Rittschof D (2000) Predation-reproduction conflict resolution in the hermit crab, Clibanarius vittatus. Ethology 106:811-818

Juanes F (1992) Why do decapod crustaceans perfer smallsized molluscan prey? Mar Ecol Prog Ser 87:239-249

Kellogg CW (1976) Gastropod shells: a potentially limiting resource for hermit crabs. J Exp Mar Biol Ecol 22:101-111

Kuhlmann ML (1992) Behavioral avoidance of predation in an intertidal hermit crab. J Exp Mar Biol Ecol 157:143-158

LaBarbera M, Merz RA (1992) Postmortem changes in strength of gastropod shells: evolutionary implications for hermit crabs, snails, and mutual predators. Paleobiology 18:367-377

Lau CJ (1987) Feeding behavior of the Hawaiian slipper lobster, Scyllarides squammosus, with a review of decapod crustacean tactics on molluscan prey. Bull Mar Sci 41: 378-391

Leite FPP, Turra A, Gandolfi SM (1998) Hermit crabs (Crustacea: Decapoda: Anomura), gastropod shells and environmental structure: their relationship in southeastern Brazil. J Nat Hist 32:1599-1608

Lively CM (1988) A graphical model for shell-species selection by hermit crabs. Ecology 69:1233-1238

Magalhães CA (2000) Partilha de recursos em guilda de gastrópodes predadores em costões de São Sebastião, SP. $\mathrm{PhD}$ thesis, Universidade Estadual de Campinas

Markham JC (1968) Notes on growth patterns and shellutilization of the hermit crab Pagurus bernhardus (L). Ophelia 5:189-205

McClintock TS (1985) Effect of shell condition and size upon the shell choice behavior of a hermit crab. J Exp Mar Biol Ecol 88:271-285

McLean R (1983) Gastropod shells - a dynamic resource that helps shape benthic community structure. J Exp Mar Biol Ecol 69:151-174

Mesce KA (1982) Calcium-bearing objects elicit shell selection behavior in a hermit crab. Science 215:993-995

Partdrige BL (1980) Background camouflage: an additional parameter in hermit crab shell selection and subsequent behavior. Bull Mar Sci 30:914-916

Pechenik JA, Lewis S (2000) Avoidance of drilled gastropod shells by the hermit crab Pagurus longicarpus at Nahant, Massachusetts. J Exp Mar Biol Ecol 253:17-32

Reese ES (1969) Behavioral adaptations of intertidal hermit crabs. Am Zool 9:343-355

Rittschof D (1980) Chemical attraction of hermit crabs and other attendants to gastropod predation sites. J Chem Ecol 6:103-118

Ross DM (1971) Protection of hermit crabs (Dardanus spp.) from octopus by commensal sea anemones (Calliactis spp.). Nature 230:401-402

Rossi AC, Parisi V (1973) Experimental studies of predation by the crab Eriphia verrucosa on both snail and hermit crab occupants of conspecific gastropod shells. Boll Zool 40:117-185

Scarratt AM, Godin JGJ (1992) Foraging and antipredator decisions in the hermit crab Pagurus acadianus (Benedict). J Exp Mar Biol Ecol 156:225-238

Shoup JB (1968) Shell opening by crabs of the genus Callappa. Science 160:887-888

Silliman BR, Bertness MD (2002) A trophic cascade regulates salt marsh primary production. Proc Natl Acad Sci USA 99: 10500-10505

Spight TM (1977) Availability and use of shells by intertidal hermit crabs. Biol Bull (Woods Hole) 152:120-133

Taylor PR (1981) Hermit crab fitness: the effect of shell condition and behavioral adaptations on environmental resistance. J Exp Mar Biol Ecol 52:205-218

Turra A (2003) Shell condition and adequacy of three sympatric intertidal hermit crab populations. J Nat Hist 37 : 1781-1796

Turra A, Denadai MR (2001) Desiccation tolerance of four sympatric tropical intertidal hermit crabs (Decapoda, Anomura). Mar Freshw Behav Physiol 34:227-238

Turra A, Leite FPP (1999) Population structure and fecundity of the hermit crab Clibanarius antillensis Stimpson 1862 (Anomura, Diogenidae) in south-eastern Brazil. Bull Mar Sci 64:281-289

Turra A, Leite FPP (2001) Fecundity of three sympatric populations of hermit crabs. Crustaceana 74:1019-1027

Turra A, Leite FPP (2002) Shell utilization patterns of a tropi- 
cal intertidal hermit crab assemblage. J Mar Biol Assoc UK 82:97-107

Turra A, Leite FPP (2003) The molding hypothesis: linking shell use with hermit crab growth, morphology and shellspecies selection. Mar Ecol Prog Ser 265:155-163

Turra A, Jacobucci JB, Araújo FMP, Leite FPP (2000) Spatial distribution of four sympatric species of hermit crabs (Decapoda, Anomura). In: Klein JCV, Schram FR (eds) The biodiversity crisis and crustacea. AA Balkema, Rotterdam, p 261-273

Vance RR (1972a) Competition and mechanism of coexistence in three sympatric species of intertidal hermit crabs. Ecology 53:1062-1074

Vance RR (1972b) Role of shell adequacy in behavioral

Editorial responsibility: Otto Kinne (Editor-in-Chief) Oldendorf/Luhe, Germany interactions involving hermit crabs. Ecology 53:1075-1083 Vermeij GJ (1978) Biogeography and adaptation. Harvard University Press, Cambridge, MA

Wilber TPJ, Herrnkind WF (1984) Predaceous gastropods regulate new-shell supply to salt marsh hermit crabs. Mar Biol 79:145-150

Yamada SB, Boulding EG (1998) Claw morphology, prey size selection and foraging efficiency in generalist and specialist shell-breaking crabs. J Exp Mar Biol Ecol 220: 191-211

Zar JH (1999) Biostatistical analysis. Prentice Hall, Englewood Cliffs, NJ

Zisper E, Vermeij GJ (1978) Crushing behavior of tropical and temperate crabs. J Exp Mar Biol Ecol 31:155-172

Submitted: January 20, 2003; Accepted: October 12, 2004

Proofs received from author: January 19, 2005 